\title{
Cloning, characterization and expression analysis of coagulation factor II gene in grass carp (Ctenopharyngodon idella)
}

\author{
B.H. Xu' ${ }^{1 *}$, K.J. Chen ${ }^{1 *}$, Y.B. Yao', Q.L. Liu' ${ }^{1}$, T.Y. Xiao ${ }^{1}$, J.M. Su² and H.Z. Peng ${ }^{1}$ \\ ${ }^{1}$ College of Animal Science and Technology, Hunan Agricultural University, \\ Changsha, China \\ ${ }^{2}$ College of Animal Veterinary and Medicine, Hunan Agricultural University, \\ Changsha, China \\ *These authors contributed equally to the study. \\ Corresponding author: T.Y. Xiao \\ E-mail: xiaotiaoyi605@163.com \\ Genet. Mol. Res. 14 (4): 13764-13778 (2015) \\ Received April 15, 2015 \\ Accepted August 18, 2015 \\ Published October 28, 2015 \\ DOI http://dx.doi.org/10.4238/2015.October.28.39
}

\begin{abstract}
Here, we characterized the structure and function of the coagulation factor II (FII) gene in grass carp and determined its role in coagulation mechanisms. The Fll gene EST was obtained using a constructed splenic transcriptome database; the full-length Fll gene sequence was obtained by $3^{\prime}$ and $5^{\prime}$ RACE. The open reading frame (ORF) of Fll was cloned and the full-length gene was found to be 1718 bp, with an ORF of $1572 \mathrm{bp}$; the gene contained a $25 \mathrm{bp} 5$ '-untranslated region (UTR) and 108 bp 3'-UTR. The ORF encoded 524 amino acids, including 74 alkaline amino acids (arginine and lysine) and 69 acidic amino acids (aspartic acid and glutamic acid). The theoretical pl was 6.22. The calculated instability index (II) was 39.81 , indicating that FII was a stable protein; the half-life period was predicted to be approximately $30 \mathrm{~h}$. Amino acid sequence comparisons indicated that grass carp Fll showed most similarity $(71 \%)$ to Fll of Takifugu rubripes, followed by Oplegnathus fasciatus ( $48 \%$ similarity) and Larimichthys crocea ( $47 \%$ similarity). A real-time reverse transcription PCR analysis showed that under normal
\end{abstract}


circumstances, Fll was most highly expressed in the liver, followed by the gill, spleen, thymus, and head-kidney $(P<0.001)$. After injection of the grass carp reovirus 873 (GCRV873), the pattern of Fll expression was significantly altered $(P<0.001)$; gene expression was high after injection, suggesting a response involving the initiation of the coagulation system and defense of the body in combination with the platelet and complement system.

Key words: Grass carp; Coagulation factor; Grass carp reovirus 873; Prothrombin; Grass carp hemorrhagic disease; Coagulation

\section{INTRODUCTION}

Grass carp (Ctenopharyngodon idella), family Cyprinidae, is an herbivorous freshwater fish widely distributed in the major river systems of China (Chen et al., 2012). The species is also used for fish farming in China where it has an annual production of over 1 million tons; the fish is characterized as delicious and nutritious, and it grows rapidly and has a low cost of breeding (Ye et al., 2012). Recently, increased disease outbreaks, such as bacterial, viral, and protozoan infections have become a major problem for grass carp farming (Zhang et al., 2013). Grass carp hemorrhagic disease, which is caused by the grass carp reovirus (GCRV), is the one of the most severe of the infectious diseases that affect the species and is characterized by a long season, fast transmission, and high risk. Infected fish can suffer severe hemorrhages and have an increased risk of mortality; these effects cause significant economic losses (Su et al., 2012).

The immune system of grass carp has been extensively studied; this system includes processes for specific immunity (e.g., lysozyme, superoxide dismutase, complements C3, C4, and interferon) and non-specific immunity (e.g., leukocytes, phagocytes, and leukomonocytes in the blood circulation system) (Jin et al., 2013). Vertebrates are known to have thirteen types of coagulation factor (factors I - XIII) in their blood, and these factors play important roles in the process of coagulation, anticoagulation and fibrinolysis in their tissues (Liu et al., 2013). Coagulation factors are produced in the liver (Abel et al., 2011). The factors can act on most types of physical damage resulting from bacterial or viral infection and have important functions in innate immunity and adaptive responses in the body (Tassanakajon et al., 2013). Coagulation factor II, also known as prothrombin, is a vitamin-K-dependent blood coagulating protein that can be converted into thrombin by coagulation factors $\mathrm{X}, \mathrm{V}$ and others (Eerenberg et al., 2011). The gene for coagulation factor II (FII) is located on grass carp chromosome 11 (11p-q12) and has 14 exons and 13 introns and encodes a protein with a relative molecular mass of approximately $72,000 \mathrm{Da}$ (Kalamchi, 1987). Prothrombin can not only activate thrombin with the help of factor VII and calcium $\left(\mathrm{Ca}^{2+}\right)$ factor, but also functions in a negative feedback mechanism to avoid thrombosis due to excessive thrombin formation (Peyvandi et al., 2012). Coagulation is one of the principal body defense systems in grass carp. Coagulation factors are mainly found in the blood lymph and blood cells and are divided two types, main coagulation factors and auxiliary coagulation factors (Liu et al., 2013). Although the Fll gene sequence and the structure and function of FII protein in dogs, mice, cattle, rabbits, and other mammals is known, there is considerably less understanding of coagulation processes and coagulation factors in fish (Wong et al., 2010; Solomon et al., 2011). In the present study, we characterize the structure and function of the grass carp Fll gene in order to elucidate its role in coagulation mechanisms in this species. 


\section{MATERIAL AND METHODS}

\section{Ethics statement}

Approval for the study was obtained from the Institutional Animal Ethics Committee of Hunan Agricultural University. All experiments were conducted in strict accordance with the established Guide for the Care and Use of Laboratory Animals of the National Institutes of Health

\section{Subjects}

A one-year-old healthy grass carp was collected from the aquaculture base of the Hunan Agricultural University. This fish was temporarily kept in an aquarium in the laboratory for 2 days without feeding. The aquarium was filled with tap water $(\mathrm{pH} 7.0)$ that had been aerated for 4 days and contained 7.5-8.2 mg/L dissolved oxygen, at a temperature of $20 \pm 1.5^{\circ} \mathrm{C}$. The tools (scissors, tweezers, and blade) for vivisection were washed and wrapped up with tin box, baked at $180{ }^{\circ} \mathrm{C}$ for $8 \mathrm{~h}$ and then cooled to room temperature. The fish was killed humanely, and spleen, liver, headkidney, thymus, and gill tissues were collected. These tissues were used for extraction of total RNA and to obtain the full sequence of the grass carp Fll gene.

Analysis of Fll expression was analyzed using one-year-old healthy grass carp ( $\mathrm{N}=$ 180 , mean body weight $=120 \pm 10 \mathrm{~g}$ ) that had been temporarily housed in an aquarium in the laboratory for 2 days. The fish were randomly divided into 2 equally-sized groups (control and infected groups) and were placed into 2 aquaria for each group. Control grass carp were injected with $0.65 \%$ physiological fish saline at the base of pectoral fin; the infected group was injected with $0.5 \mathrm{~mL}$ standard strain GCRV873, also at the base of the pectoral fin. Both groups were maintained in well-aerated water at $28^{\circ} \mathrm{C}$. Fifteen fish from each group were selected at random at six different time points after injection: 0, 24, 48, 72, 96, and $138 \mathrm{~h}$. Spleen, liver, head-kidney, thymus, and gill tissues were collected. Total RNAs were extracted from the tissues. Samples from 3 fish per treatment group and time interval were used for analysis of gene expression.

\section{Primer design}

Primers were designed using published conserved FII gene sequences: FII-Mid (F) and FIIMid (R) were used cloning the conserved region of FII; FII-3" and 3'-Adaptor were used for 3' RACE; FII-5' and 5'-Adaptor were used for 5' RACE. FII was the gene specific primer used for quantitative expression analysis, and $\beta$-actin was used as the internal control. The above primers were designed by Primer 5.0 and synthesized by the Shanghai Sangon Biotechnology Co. Ltd. (Table 1).

\section{Extraction of total RNA from grass carp tissues}

The extraction of total RNAs from grass carp tissues was carried out as described in the experimental procedures of the column animal RNA-out Kit (Beijing Tianenze Gene Technology Co., Ltd, Beijing, China). The collected spleen, liver, head-kidney, thymus, and gill tissues were placed separately in 10-mL centrifuge tubes and $100 \mathrm{mg} / \mathrm{mL}$ Trizol lysate was added. The tissues were homogenized on ice and $200 \mu \mathrm{L}$ of each lysate was transferred to a centrifuge tube (pretreated with $1.5 \mathrm{~mL}$ diethyl pyrocarbonate, DEPC). Then, $800 \mu \mathrm{L}$ RNA extraction solution A for animal tissues, and $200 \mu \mathrm{L}$ chloroform was added. After mixing, the suspension was centrifuged at 
$2000 \mathrm{rpm}$ at $4^{\circ} \mathrm{C}$ for $5 \mathrm{~min}$. A 200-300 $\mu \mathrm{L}$ aliquot of the supernatant was placed into a DEPC-treated centrifuge tube and an equal volume of RNA extraction solution B for animal tissues was added. Half of the solution was added to an adsorption column in a collection tube; this was centrifuged for $30 \mathrm{~s}$ at $12000 \mathrm{rpm}$ and the flow-through liquid was discarded. The other half of the solution was then added to the adsorption column and the procedure was repeated. A column washing liquid $(700 \mu \mathrm{L})$ was added and centrifuged for $30 \mathrm{~s}$ at $12000 \mathrm{rpm}$; this step was repeated with $300 \mu \mathrm{L}$ of the column washing liquid. The adsorption column was transferred to another DEPC-treated centrifuge tube and $50 \mu \mathrm{L}$ RNA eluent was added; the tube was centrifuged for $30 \mathrm{~s}$ at $12000 \mathrm{rpm}$, and the eluate, containing the RNA, was collected. After extraction of the RNA, the quality of the isolated material was checked using $1 \%$ gel electrophoresis (Wang et al., 2015) .

Table 1. Primer sequences used in the present study.

\begin{tabular}{|c|c|}
\hline Primer name & Sequences $\left(5^{\prime}-3^{\prime}\right)$ \\
\hline FII-Mid (F) & AAGTTTGTGGAGGAAGGTGGTG \\
\hline FII-Mid (R) & TGACCGAGGTGGAATTGCGACA \\
\hline$F I I-3^{\prime}(F)$ & TGAAATCATTGTCCACСCTA \\
\hline FII-3' (R) & ССTGTCTGTCTGCCCACCAA \\
\hline 3'-Adaptor & CTGATCTAGAGGTACCGGATCC \\
\hline 3'-Adaptor (dT) & CTGATCTAGAGGTACCGGATCC $(\mathrm{T})_{14}$ \\
\hline Fll-5' (F) & TGGGCAGACAGACAGGATG \\
\hline Fll-5' (R) & AGAGCAATGTCTCGGTTCAGG \\
\hline 5'-Adaptor & GACTCGAGTCGACATCGA \\
\hline 5'-Adaptor (dT) & GACTCGAGTCGACATCGA $(T)_{17}$ \\
\hline M13/pUC (F) & GTTGTAAAACGACGGCCAG \\
\hline M13/pUC (R) & CAGGAAACAGCTATGACC \\
\hline$F I I(F)$ & TGGGCAGACAGACAGGA \\
\hline$F I I(R)$ & СССTAAATACAACTGGAAGGAA \\
\hline$\beta$-actin (F) & GCCGTGACCTGACTGACTA \\
\hline$\beta$-actin (R) & TCAAGAGCCACATAGCAGAG \\
\hline
\end{tabular}

$\mathrm{F}=$ Forward; $\mathrm{R}=$ Reverse.

\section{Amplification of FIl gene cDNAs}

High-quality cDNAs were synthesized as described in the instructions for the Revert Aid First Strand cDNA Synthesis Kit reverse transcription Kit (MBI, America). Briefly, the RNA samples were placed in $0.2 \mathrm{~mL}$ centrifuge tubes on ice; a reaction mix of $20 \mu \mathrm{L}$ was prepared by adding $6 \mu \mathrm{L}$ nuclease-free water, $5 \mu \mathrm{L}$ RNA, $1 \mu \mathrm{L}$ o1igo(dT) 18, $4 \mu \mathrm{L} 5 \mathrm{X}$ reaction buffer, $2 \mu \mathrm{L} 10 \mathrm{mM}$ dNTP mix, $1 \mu \mathrm{L}$ RNase inhibitor $(20 \mu / \mu \mathrm{L})$, and $1 \mu \mathrm{L}$ reverse transcriptase $(200 \mu / \mu \mathrm{L})$.

The synthesized cDNAs were used as templates for PCR amplification using the Fll-Mid (F) and FII-Mid (R) primers, supplemented with Taq enzyme and premix (Promega Company). The reaction mix of $25 \mu \mathrm{L}$ contained $12.5 \mu \mathrm{L}$ premix, $1 \mu \mathrm{L}$ cDNA, $0.5 \mu \mathrm{L}$ FII-Mid (F), $0.5 \mu \mathrm{L}$ FII-Mid (R), and $10.5 \mu \mathrm{L}$ nuclease-free water. The reaction conditions were pre-denaturation at $94^{\circ} \mathrm{C}$ for $5 \mathrm{~min}$, denaturation at $94^{\circ} \mathrm{C}$ for $30 \mathrm{~s}$, annealing at $58^{\circ} \mathrm{C}$ for $30 \mathrm{~s}$, and extension at $72^{\circ} \mathrm{C}$ for 2 min. The quality of the amplification products were checked using $1.0 \%$ agarose gel electrophoresis; unused products were stored at $-80^{\circ} \mathrm{C}$.

\section{3'RACE of grass carp Fll gene 3'-end cDNA}

High-quality cDNA was synthesized following the manufacturer instructions using a Revert Aid First Strand cDNA Synthesis Kit reverse transcription Kit (MBI, America). Ten $\mu \mathrm{L}$ nuclease-free 
water was added to a sterile 0.2-mL centrifuge tube, along with $1 \mu \mathrm{L}$ 3' RACE O1igo(T)-Adaptor, and $1 \mu \mathrm{L}$ total RNA; the tube was centrifuged for $30 \mathrm{~s}$ at $12000 \mathrm{rpm}$, then incubated in a water-bath for $5 \mathrm{~min}$ at $65^{\circ} \mathrm{C}$. After $1 \mathrm{~min}$ on ice, $4 \mu \mathrm{L} 5 \mathrm{X}$ reaction buffer, $2 \mu \mathrm{L} 10 \mathrm{mM}$ dNTP Mix, $1 \mu \mathrm{L}$ Ribolock RNase inhibitor, and $1 \mu \mathrm{L}$ Revert Aid M-Mulv Reverse was added to the tube and centrifuged for $30 \mathrm{~s}$ at $12000 \mathrm{rpm}$. The tube was then incubated in a water-bath for $90 \mathrm{~min}$ at $42^{\circ} \mathrm{C}$, extended at $70^{\circ} \mathrm{C}$ for $5 \mathrm{~min}$ and finally terminate reactions. The cDNA was used as the template for PCR with the specific primers and universal primers for 3' RACE O1igo (T)-Adaptor. The reaction mix of $25 \mu \mathrm{L}$ contained $12.5 \mu \mathrm{L}$ premix, $1 \mu \mathrm{L}$ cDNA, $0.5 \mu \mathrm{L}$ FII-3' (N), $0.5 \mu \mathrm{L}$ Adaptor (dT), and $10.5 \mu \mathrm{L}$ nuclease-free water. The reaction conditions were: pre-denaturation at $94^{\circ} \mathrm{C}$ for $5 \mathrm{~min}, 30$ cycles of denaturation at $94^{\circ} \mathrm{C}$ for $30 \mathrm{~s}$, annealing at $58^{\circ} \mathrm{C}$ for $30 \mathrm{~s}$, and extension at $72^{\circ} \mathrm{C}$ for 2 min; and a final extension at $72^{\circ} \mathrm{C}$ for $10 \mathrm{~min}$. FII-3'(W) and 3' RACE Adaptor nested primers were used with the same reaction conditions using the PCR product (diluted 50 times) as the template. The quality of the amplified products was confirmed using 1.0\% agarose gel electrophoresis; unused product was stored at $-80^{\circ} \mathrm{C}$.

\section{5' RACE}

The 3' RACE O1igo (T)-Adaptor for 3'-end cDNA synthesis was replaced with FII-5' (N), and the $5^{\prime}$-end cDNA synthesis used the experience of the first chain of the 3 ' RACE end cDNA synthesis. cDNA was purified using the manufacturer instructions for the DNA Fragment Purification Kit Purification Kit (TaKaRa Company), and 3' poly A was added and amplified according to the instructions for the Terminal deoxynucleotidyl transferase Kit (TaKaRa Company). The reaction mix of $50 \mu \mathrm{L}$ contained $20 \mu \mathrm{L}$ diluted cDNA, $5 \mu \mathrm{L}$ PCR Buffer, $10 \mu \mathrm{L} 10 \mathrm{mM}$ dNTPs, $1.6 \mu \mathrm{L} 10 \mathrm{mM}$ (dT) 17-Adaptor, $3.2 \mu \mathrm{L} 100$ mM Adaptor, $3.2 \mu \mathrm{L}$ FII-5' (W), $1 \mu \mathrm{L}$ Taq, and $6 \mu \mathrm{L}$ nuclease-free water. The amplification conditions were: pre-denaturation at $94^{\circ} \mathrm{C}$ for $5 \mathrm{~min}$, denaturation at $94^{\circ} \mathrm{C}$ for $1 \mathrm{~min}$, annealing at $58^{\circ} \mathrm{C}$ for $5 \mathrm{~min}$, and extension at $74^{\circ} \mathrm{C}$ for $40 \mathrm{~min}$; then 30 cycles of denaturation at $94^{\circ} \mathrm{C}$ for $40 \mathrm{~s}$, annealing at $58^{\circ} \mathrm{C}$ for $1 \mathrm{~min}$, extension at $72^{\circ} \mathrm{C}$ for $3 \mathrm{~min}$; finally, pre-denaturation at $94^{\circ} \mathrm{C}$ for $40 \mathrm{~s}$, annealing at $58^{\circ} \mathrm{C}$ for $1 \mathrm{~min}$, and extension at $72^{\circ} \mathrm{C}$ for $5 \mathrm{~min}$. The quality of the amplification products was checked using $1.0 \%$ agarose gel electrophoresis; unused product was stored at $-80^{\circ} \mathrm{C}$.

\section{Recovery, cloning and sequencing of target bands}

PCR products were recovered using an agarose gel DNA extraction kit. The recovered PCR products were connected to $\mathrm{pUCm}-\mathrm{T}$ carrier and then transformed into competent cells of Escherichia coli DH5a; successful transformation was confirmed using the standard screen on a plate with Amp/IPrG/X-Gal. Positive clones were amplified by culturing and then sent to the Shanghai Sangon Biotechnology Co. Ltd. for sequencing.

\section{Analysis of grass carp FII gene cDNA full-length sequences and the deduced amino acid sequences}

A BLAST analysis was performed using the NCBI database to determine the sequences of the positive clones; a final sequence was constructed using Primer5.0 and DNAMAN software. The full-length sequence of Fll gene cDNA was placed in the NCBI database, and combined DNA STAR, DNAMAN, Primer5.0 and other biological software were used to identify the open reading frame 
(ORF) sequence, and the sequence of the predicted protein. The protein sequence was placed into the NCBI database to identify homologous protein sequences. Predict Protein, HMM2.0 and other online software was used to predict the two- dimensional and three- dimensional structures of the protein. MEGA4.0 software and the neighbor joining method were combined to construct a phylogenetic tree. A phylogenetic tree of the Fll gene of grass carp and 15 other species was edited by the Tree view program with a bootstrap value of 500 .

\section{Reverse transcription PCR (RT-PCR) expression analysis of grass carp FIl gene}

RNA samples were obtained from tissues of 3 grass crap that had been injected with the toxin and from three control fish at every sampling interval. After reverse transcription, the cDNAs were checked for concentration and purity. The amplification conditions were as described by the operating manual for SYBRJ Green Real time PCR Master Mix and the fluorescence quantitative $P C R$ instrument (ABI 7300hT). The primer sequences are shown in Table 1. Each reaction mix of $25 \mu \mathrm{L}$ contained $1 \mu \mathrm{L}$ cDNA template, $12.5 \mu \mathrm{L}$ SYBR Green Real time PCR Master Mix, $0.5 \mu \mathrm{L}$ FII (F), $0.5 \mu \mathrm{L} F / I(\mathrm{R})$, and $10.5 \mu \mathrm{L}$ nuclease-free water. The amplification conditions were predenaturation at $94^{\circ} \mathrm{C}$ for $5 \mathrm{~min}$, and then 35 cycles of denaturation at $94^{\circ} \mathrm{C}$ for $30 \mathrm{~s}$, annealing at $58^{\circ} \mathrm{C}$ for $30 \mathrm{~s}$, and extension at $72^{\circ} \mathrm{C}$ for $45 \mathrm{~s}$; finally, extension at $72^{\circ} \mathrm{C}$ for $10 \mathrm{~min}$. The sequence detection system (SDS version 1.4) of the fluorescence quantitative PCR instrument was applied for data collection and analysis and the establishment of a standard curve for each sample. The $\mathrm{Ct}$ value, measured by the $2^{-\Delta C t}$ method, was used to detect the amplification efficiency of the grass crap FIl gene and $\beta$-actin. The relative expression level was calculated by analyzing the expression in different tissues after resolving the amplification specificity of the curve primer.

\section{Statistical analysis}

Statistical analysis was performed using SPSS version 19.0. Data are presented as mean \pm standard deviation (mean \pm SD) and were tested for normality. Comparison between two groups was performed using $t$-tests, and comparisons among groups using one-way analysis of variance (ANOVA); homogeneity of variance test was carried out before the analysis. LSD-t-test was applied for the paired-comparisons among multiple groups. $P<0.05$ was selected as statistically significant.

\section{RESULTS}

\section{RNA quality detection}

The quality of the extracted total RNA was checked using $1 \%$ agarose gel electrophoresis. The analysis identified two obvious bands, one at $28 \mathrm{~S}$ and the other at $18 \mathrm{~S}$ (Figure 1), suggesting the recovery of high quality RNA without degradation that could be used for synthesis of first strand cDNA. The OD260/OD280 and OD260/OD230 values were approximately 2.0, and were therefore consistent with the purity requirements.

\section{3' RACE and 5' RACE results}

The 3' RACE and 5' RACE yielded PCR products of 400-500 bp and 700-800 bp, respectively (Figure 2 ). 


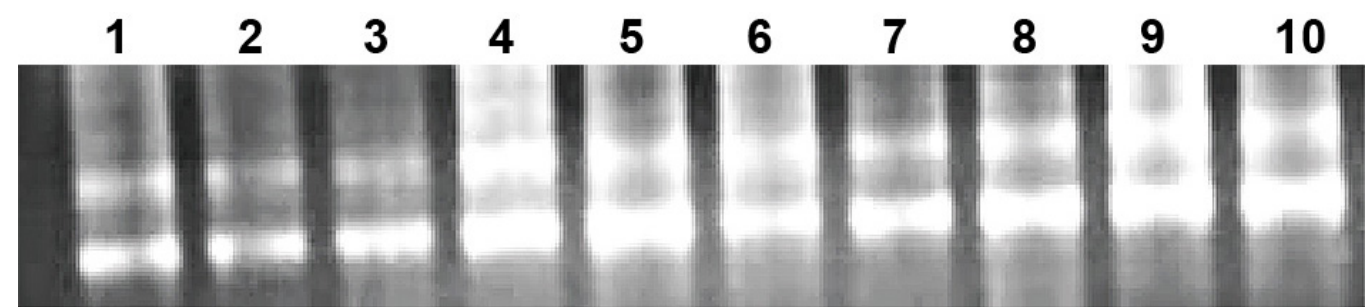

Figure 1. Total RNA from various tissues of grass carp (1 and 2, gill; 3 and 4, head-kidney; 5 and 6 , thymus; 7 and 8 , spleen; 9 and 10, liver).

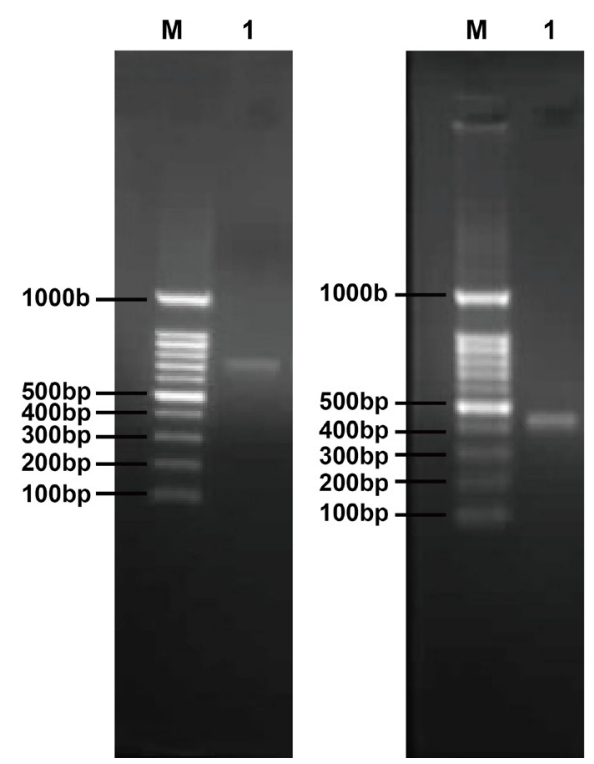

Figure 2. Grass carp coagulation factor $(\mathrm{F}) / /$ gene: $\mathrm{A} 1$ : 5' RACE products. B1: 3' RACE products. M: 100 bp DNA ladder.

\section{Splicing and analysis of grass carp FII gene full-length sequences}

The data from PCR and RACE analyses on the grass carp Fll gene were submitted to GenBank (accession No. KF937388). The constructed full-length sequence of the gene was 1718 bp, with an ORF of 1572 bp a 25 bp 5'-UTR and a 108 bp 3'-UTR. There were 2 AATAAA motifs in the mRNA and 2 signal ATTTA sequences related to the stability of mRNA. The contents and ratios of the various bases were as follows: A, 516 (30.05\%); G, 438 (25.51\%); T, 414 (24.11\%); C, 349 (20.33\%); C+G, $787(45.84 \%) ; \mathrm{Tm}=83.74^{\circ} \mathrm{C}$. The cDNA sequence and the deduced amino acid sequence are shown in Figure 3.

\section{Analysis of grass carp FII gene amino acid sequence}

The grass carp FII protein sequence was interrogated using ExPasy online software (http://web.expasy.org/protparam). This showed that the 524 transcribed and translated protein sequences of grass carp Fll gene contained $\mathrm{C}_{2658}{ }_{n 4147} \mathrm{~N}_{739} \mathrm{O}_{774} \mathrm{~S}_{28}$, among which there were 69 
negatively charged amino acid residues (aspartic acid and glutamic acid) and 74 positively charged amino acid residues (arginine and lysine). The theoretical pl was 6.22. The calculated instability index (II) was 39.81, indicating a stable protein; the half-life period was estimated at approximately $30 \mathrm{~h}$. The predicted protein sequence of grass carp Fll contained 20 different amino acids, with a relatively high proportion of lysine (Lys) (8.2\%) and glutamate (7.8\%) and a low proportion of methionine $(1.7 \%)$ (Table 2, Figure 4).

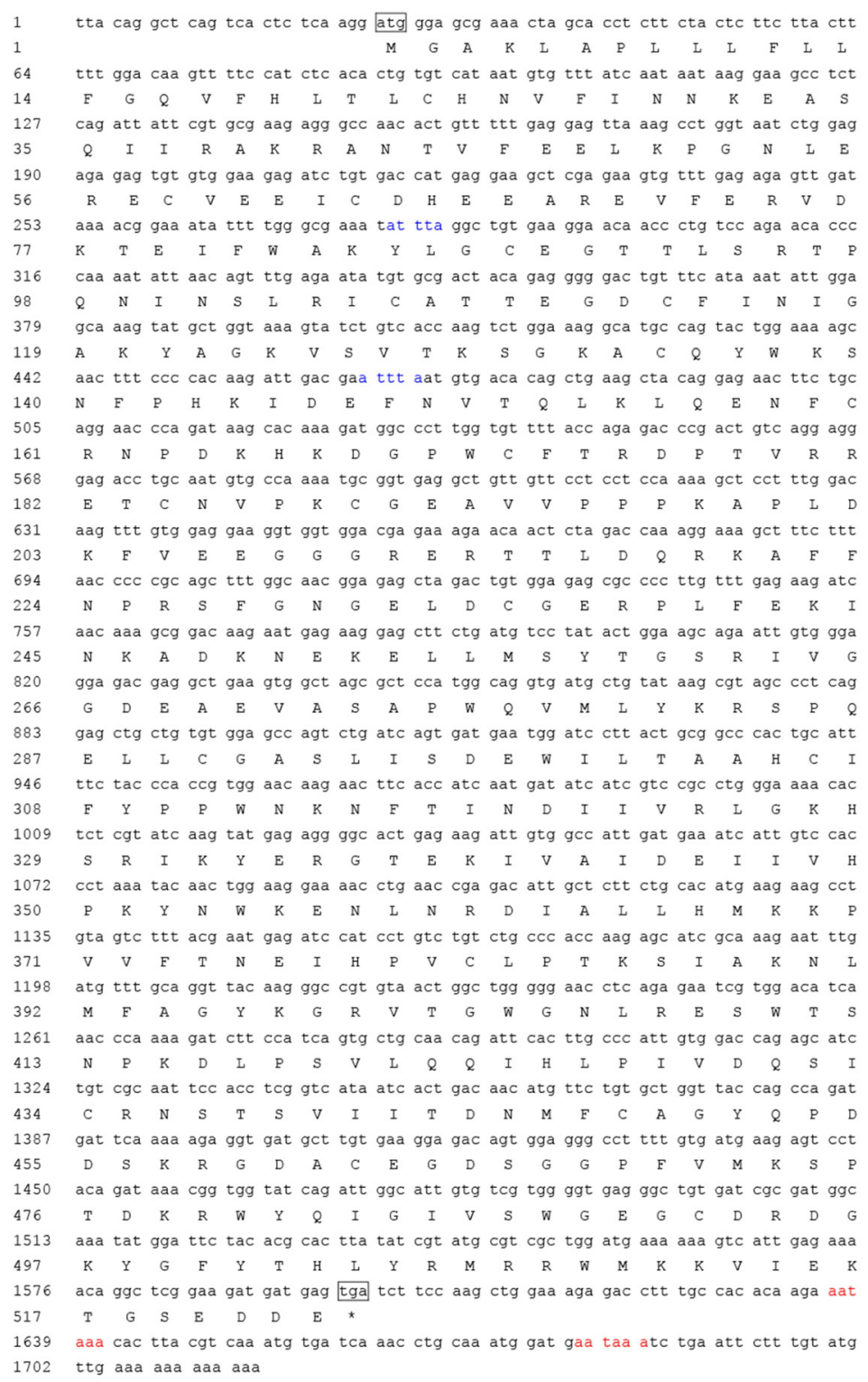

Figure 3. Grass carp Fll full-length cDNA sequence and protein sequence. The 3' UTR includes two poly-A tail signaling sequences (AATAAA; shown in red) and two rapid degradation of mRNA sequences (ATTTA; shown in blue). 


\begin{tabular}{|c|c|c|c|c|c|}
\hline Name of amino acid & Triplet abbreviation & One-letter abbreviation & Number & $\mathrm{Mol} / \mathrm{mol}(\%)$ & Property \\
\hline Aspartic acid & Asp & $\mathrm{D}$ & 28 & 5.34 & Acidic \\
\hline Glutamic acid & Glu & $E$ & 41 & 7.82 & Acidic \\
\hline Arginine & Arg & $\mathrm{R}$ & 31 & 5.92 & Basic \\
\hline Histidine & His & $\mathrm{H}$ & 12 & 2.29 & Basic \\
\hline Lysine & Lys & $\mathrm{K}$ & 43 & 8.21 & Basic \\
\hline Serine & Ser & $S$ & 26 & 4.96 & Hydrophilic \\
\hline Threonine & Thr & $\mathrm{T}$ & 28 & 5.34 & Hydrophilic \\
\hline Glycine & Gly & G & 38 & 7.25 & Hydrophilic \\
\hline Cysteine & Cys & $\mathrm{C}$ & 19 & 3.63 & Hydrophilic \\
\hline Glutamine & Gln & $Q$ & 14 & 2.67 & Hydrophilic \\
\hline Asparagine & Asn & $\mathrm{N}$ & 29 & 5.53 & Hydrophilic \\
\hline Tryptophan & $\operatorname{Trp}$ & W & 12 & 2.29 & Hydrophobic \\
\hline Tyrosine & Tyr & $\mathrm{Y}$ & 14 & 2.67 & Hydrophobic \\
\hline Alanine & Ala & A & 27 & 5.15 & Hydrophobic \\
\hline Isoleucine & lle & I & 34 & 6.49 & Hydrophobic \\
\hline Leucine & Leu & $\mathrm{L}$ & 37 & 7.06 & Hydrophobic \\
\hline Methionine & Met & $\mathrm{M}$ & 9 & 1.72 & Hydrophobic \\
\hline Phenylalanine & Phe & $G$ & 24 & 4.58 & Hydrophobic \\
\hline Proline & Pro & $\mathrm{P}$ & 28 & 5.34 & Hydrophobic \\
\hline Valine & Val & V & 30 & 5.73 & Hydrophobic \\
\hline
\end{tabular}

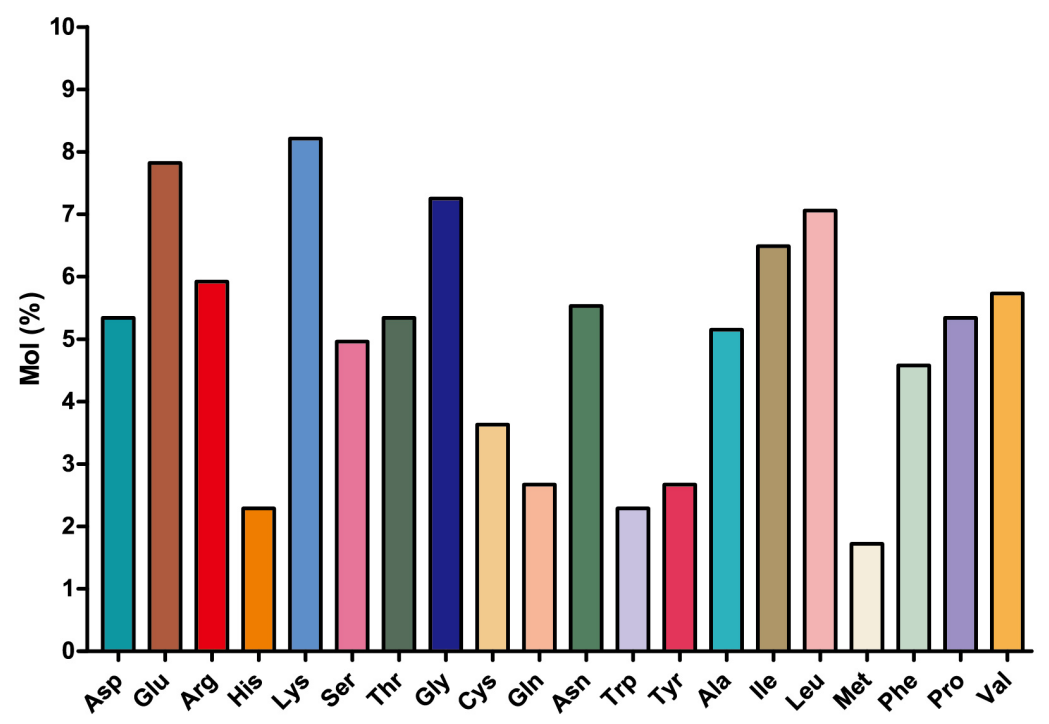

Figure 4. Amino acid frequencies in the protein encoded by the grass carp Fll gene.

\section{Prediction of the two-dimensional structure of grass carp FII protein sequence}

The two-dimensional structure of grass carp FII protein sequence was predicted using http://www.predictprotein.org/. The analysis indicated that a $\beta$-fold accounted for $17.7 \%$, an $\alpha$-helix accounted for $14.5 \%$, and the largest proportion of irregular ring structures accounted for $67.7 \%$ (Figure 5). In addition, there were some two-stage structures such as a $\beta$-angle. 


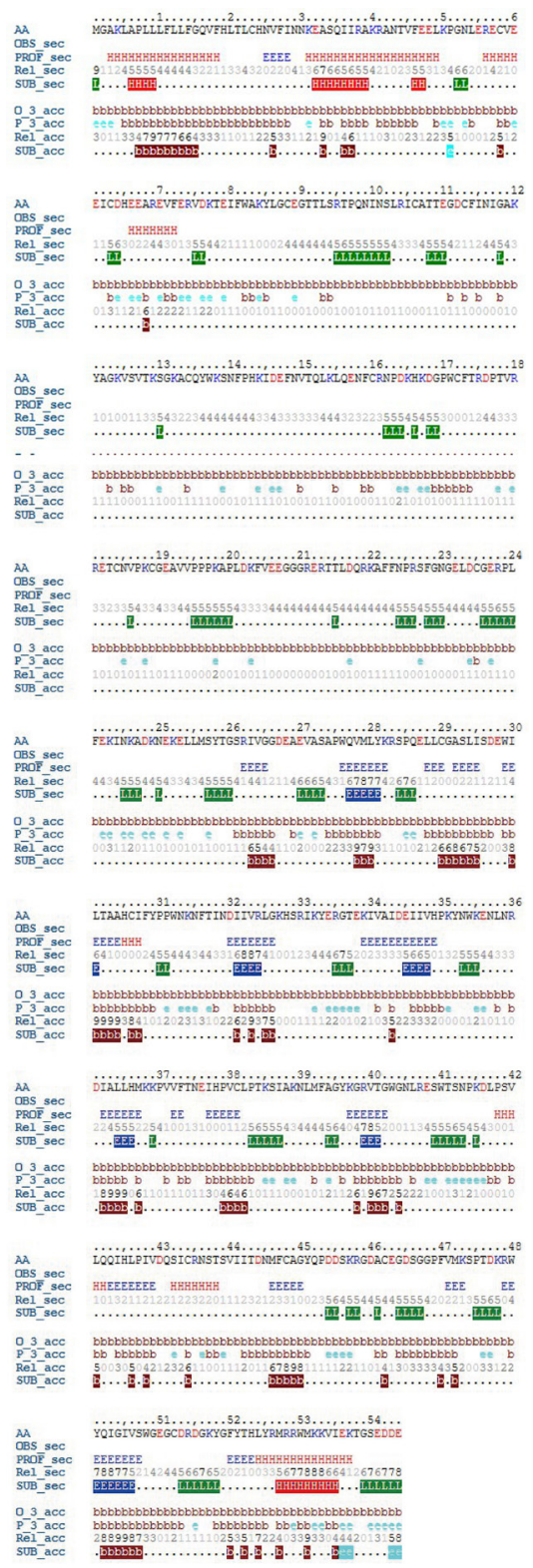

Figure 5. Prediction of the two-grade structure of the Fll protein sequence.

\section{Prediction of the three-dimensional structure of grass carp FII protein sequence}

The three-dimensional structure of the grass carp FII protein sequence was predicted using http://pdb.rcsb.org/pdb/explore.do?structureld=2QML and a model was constructed. The analysis implied that the protein contained 7 right-handed $\alpha$-helixes and $7 \beta$-folds connected by a $\beta$-angle (Figure 6). 


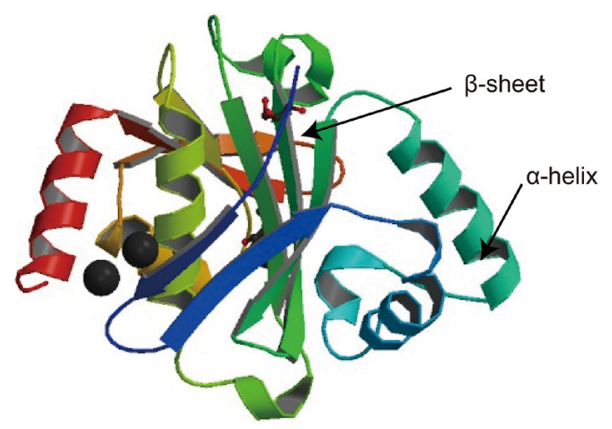

Figure 6. Model showing the predicted three-grade structure of the Fll protein sequence.

\section{Analysis of homology and molecular evolution of grass carp FII amino acid sequence}

The phylogenetic analysis of the grass carp FIl protein showed the highest similarity $(71 \%)$ with the FII protein of Takifugu rubripes (NP_001027864.1), followed by Oplegnathus fasciatus (BAM36362.1) (48\%) and Larimichthys crocea (ACA30405.1) (47\%). Clustal W software was applied to analyze the grass carp FII amino acid sequence with the amino acid sequences of other species. A phylogenetic tree was constructed using the Mega 5.0 program and the neighbor-joining method (NJ). The number of bootstrap replications was set as 500 . The phylogenetic tree is shown in Figure 7 and indicates that $T$. rubripes, $O$. fasciatus, and $L$. crocea formed a first branch, and then formed a second branch was formed with grass carp, and finally a branch with Xenopus tropicalis.

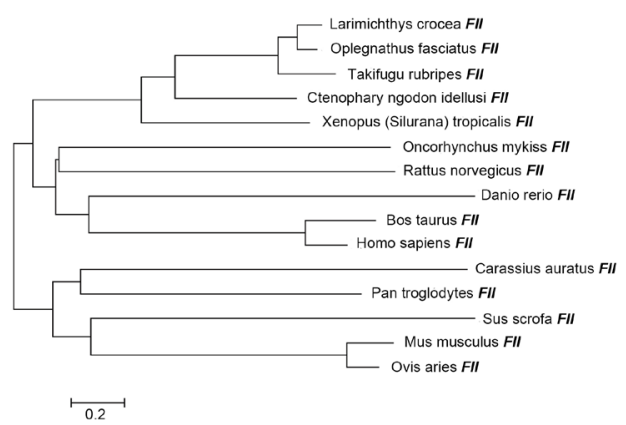

Figure 7. Phylogenetic tree of Fll genes of selected vertebrates (Larimichthys crocea ACA30405.1, Oplegnathus fasciatus BAM36362.1, Takifugu rubripes NP_001027864.1, Ctenopharyngodon idellusi KF937388, Xenopus (Silurana) tropicalis NP_001015797.1, Oncorhynchus mykiss NP_001117856.1, Rattus norvegicus EDM10105.1, Danio rerio NP_001092248.1, Bos taurus AAI34503.1, Homo sapiens EAW95778.1, Carassius auratus AG058838.1, Pan troglodytes JAA43518.1, Sus scrofa AAR99595.1, Mus musculus AAH13662.1, Ovis aries ACV04830.1).

\section{Expression of grass carp FII gene in different tissues}

A comparison of expression of the grass carp Fll gene in different tissues showed that at time point $0 \mathrm{~h}$, there were statistically different levels in the spleen, liver, head-kidney, thymus, and gill tissues $(P<0.001)$. Thus, the Fll gene displayed a tissue-specific expression pattern. The highest level of expression was detected in the liver, followed by the gill, spleen, and thymus; the head-kidney had the lowest relative expression level (Table 3, Figure 8). 


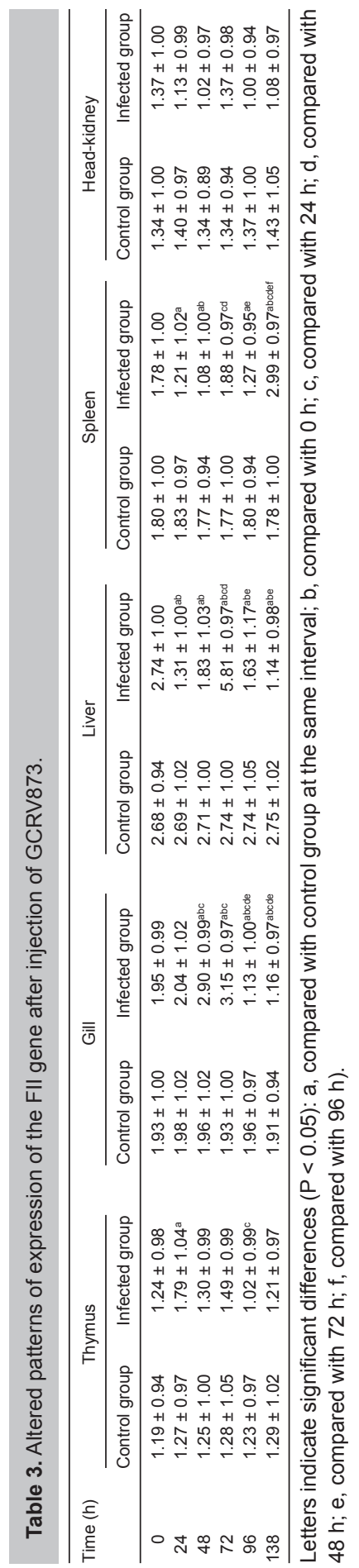




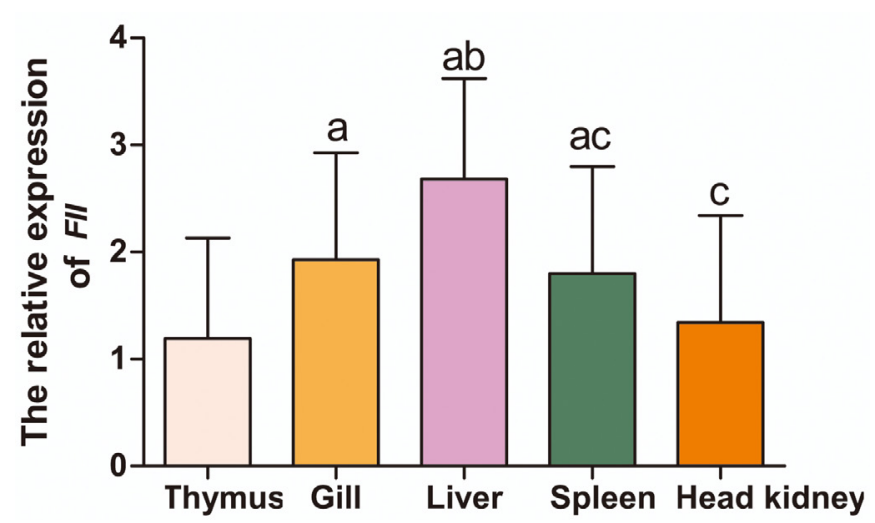

Figure 8. Fll expression levels in various tissues by quantitative RT-PCR. Different letters indicate significant differences $(P<0.05)$ : a, compared with thymus tissue; $b$, compared with gill tissue; $c$, compared with liver tissue; $d$, compared with head-kidney.

\section{Changes in grass carp FII expression after GCRV873 injection}

Immediately after injection, there was no significant difference in Fll expression in the thymus after GCRV873 injection ( $P>0.05$ ); however, at $24 \mathrm{~h}$, expression in the thymus of the infected group was significantly increased compared to the control group $(P<0.05)$. In the infected group, expression in gill tissues varied significantly among time points $(P<0.05)$. There was a sharp increase at 48 to $72 \mathrm{~h}$, and then a sharp decline at 96 to $138 \mathrm{~h}$; the difference was statistically significant compared with the control group ( $\mathrm{P}<0.05)$. After GCRV873 injection, Fll expression increased significantly at $72 \mathrm{~h}$ in liver tissues compared to the control, but decreased at $24,48,96$, and $138 \mathrm{~h}(\mathrm{P}<0.05)$. Expression of $F / l$ differed significantly in spleen tissues of the infected group between time points $(P$ $<0.05)$; expression was significantly lower within 24 to $48 \mathrm{~h}$ compared to the control group $(P<0.05)$. There was a slight increase in FII expression at $72 \mathrm{~h}$, and no significant difference was found with the control group $(P>0.05)$; the level of expression fell at $96 \mathrm{~h}$, but reached its highest level at 138 $h$ and showed a significant difference to the control group $(P<0.05)$. In the head-kidney, expression did not change significantly after GCRV873 injection ( $P>0.05)$; the level of expression fell at 48 to $72 \mathrm{~h}$, increased slightly at $72 \mathrm{~h}$, and fell again at 96 to $138 \mathrm{~h}$ at which time there was no significant difference compared to the control group $(P<0.05)$ (Table 3, Figure 9).
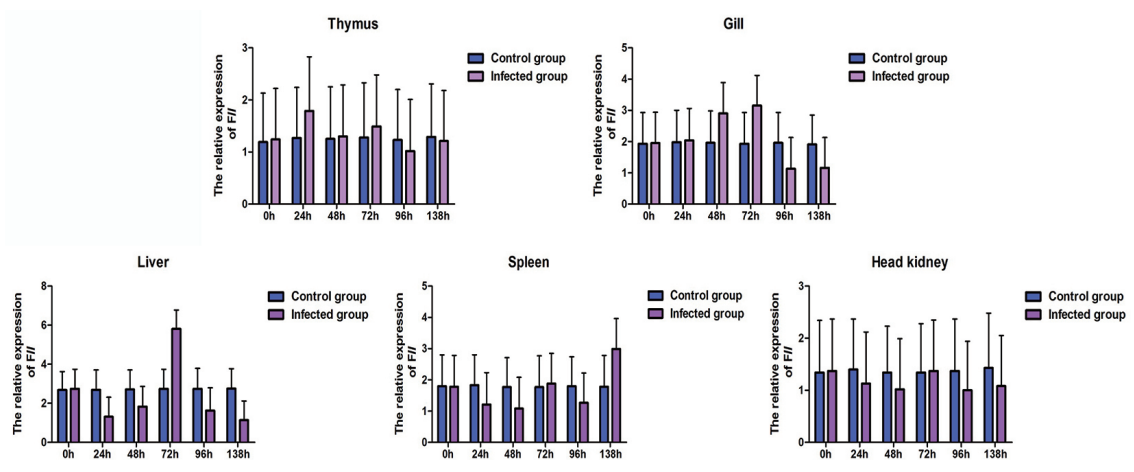

Figure 9. Altered patterns of Fll expression in tissues after the injection of GCRV873. 


\section{DISCUSSION}

Grass carp is a very important aquaculture species in China. However, its susceptibility to disease, such as hemorrhagic disease caused by GCRV, is a considerable problem (Su et al., 2012). The innate immune system in fish is a fundamental mechanism against disease agents. To date, traditional methods have proved incapable of providing adequate control of infectious diseases; however, development of molecular markers and identifying genes associated with the immune system has become a key to future development of the fishery (Zhang et al., 2013). In this study, we characterized the structure and function of the grass carp Fll gene and determined its role in the coagulation process. Cloning of related genes from other aquatic species will undoubtedly enable a better understanding of disease-resistance, be of value for breeding resistant varieties, and provide important materials and a theoretical basis for future research.

FII/prothrombin, the precursor of thrombin, is the final effector in the clotting cascade resulting in the formation of fibrin. It is the key enzyme in the balance of procoagulation and anticoagulation; it acts by enhancing coagulation through positive feedback loops and also promotes anticoagulation via the protein C pathway (Gessoni et al., 2012). In the coagulation mechanism in vertebrates, prothrombin plays a vital role in coagulation, anticoagulation and soluble protein fibrosis. Prothrombin is encoded by a housekeeping gene that is closely involved in the coagulation mechanisms of most fish, poultry, and mammals (Kang et al., 2011).

Comparison of amino acid sequences showed that the grass carp FIl protein showed similarity to that of $T$. rubripes, $O$. fasciatus and L. crocea. Thus, the grass carp FII protein is similar to the prothrombin of most fish, as the primary structure determines the advanced structure and further influences its function. The comparative similarities of the grass carp FII protein to those of $T$. rubripes, $O$. fasciatus, and $L$. crocea mirrors the direction of species evolution, which indicates that the grass carp Fll gene has a highly conserved sequence (Tang et al., 2013). In our study, the phylogenetic tree analysis showed that $T$. rubripes, $O$. fasciatus, and $L$. crocea were located in one branch, and then formed a larger branch with grass carp, and finally formed a branch with Xenopus tropicalis. This analysis confirmed conservation of the grass carp Fll gene, and was consistent with the direction of evolution of these species.

The results of the RT-PCR analysis showed that under normal circumstances, the FII gene showed highest expression in the liver, followed by the gill, spleen, thymus, and head-kidney. After injection of GCRV873, FIl expression levels in the liver, gill, and spleen were significantly altered. One possible explanation is that the immune system of grass carp is nonspecific. Thus, in the first $24 \mathrm{~h}$ after injection, the decrease of $F / l$ gene expression level was mainly due to the initiation of nonspecific immune system responses to GCRV873. However, as the period of infection continued, the limited ability of the non-specific immune system made it necessary to induce the blood coagulation system to resist the virus. In blood coagulation, thrombus formation requires the thrombin-mediated transformation of fibrinogen into fibrin; fibrous material in the inflammatory tissue clearance area plays a significant role in preventing the spread of bacteria or viruses ( $\mathrm{Li}$ et al., 2011). The liver and spleen are known to be key organs for the blood system, so at 24 to $72 \mathrm{~h}$ after injection of GCRV873, when the nonspecific immune system was exhausted, the FII gene would be upregulated. Similar to other vertebrates, the coagulation system, complement system, and immune system of grass carp show mutual promotion and adjustment (Rhee et al., 2014). Therefore, we speculate that the grass carp FII gene may encode a protein for control of hemorrhagic diseases and may thus play an important role in resistance to GCRV873.

In conclusion, the grass carp FIl gene has a high expression level after injection of 
GCRV873; this increased expression may be associated with initiation of the coagulation system along with the platelet and complement systems. Our study provides a foundation for studying the mechanism and function of the FII gene and a theoretical support for analysis of coagulation mechanisms.

\section{Conflicts of interest}

The authors declare no conflict of interest.

\section{ACKNOWLEDGMENTS}

We would like to thank our researchers for their hard work and reviewers for their valuable advice. This study was supported by a fund of the National Natural Science Foundation of China (\#31272652), National High Technology Research and Development Program of China (\#2011AA100404) and National technology System for Conventional Freshwater Fish industries of China Agriculture Research System (\#CARS-46-42).

\section{REFERENCES}

Abel R, Salam NK, Shelley J, Farid R, et al. (2011). Contribution of explicit solvent effects to the binding affinity of smallmolecule inhibitors in blood coagulation factor serine proteases. Chem Med. Chem. 6: 1049-1066.

Chen J, Li C, Huang R, Du F, et al. (2012). Transcriptome analysis of head kidney in grass carp and discovery of immunerelated genes. BMC Vet. Res. 8: 108.

Eerenberg ES, Kamphuisen PW, Sijpkens MK, Meijers JC, et al. (2011). Reversal of rivaroxaban and dabigatran by prothrombin complex concentrate: a randomized, placebo-controlled, crossover study in healthy subjects. Circulation 124: 1573-1579.

Gessoni G, Valverde S and Manoni F (2012). Evaluation of the GeneXpert assay in the detection of Factor V Leiden and prothrombin 20210 in stored, previously classified samples. Clin. Chim. Acta 413: 814-816.

Jin Y, Tian LX, Zeng SL, Xie SW, et al. (2013). Dietary lipid requirement on non-specific immune responses in juvenile grass carp (Ctenopharyngodon idella). Fish Shellfish Immunol. 34: 1202-1208.

Kalamchi S (1987). Mental nerve anaesthesia secondary to breast cancer. Dent. Update 14: 127-128.

Kang TS, Georgieva D, Genov N, Murakami MT, et al. (2011). Enzymatic toxins from snake venom: structural characterization and mechanism of catalysis. FEBS J. 278: 4544-4576.

$\mathrm{Li} \mathrm{CH}$, Chen J, Shi YH and Lu XJ (2011). Use of suppressive subtractive hybridization to identify differentially expressed genes in ayu (Plecoglossus altivelis) associated with Listonella anguillarum infection. Fish Shellfish Immunol. 31: 500-506.

Liu Q, Xu B, Xiao T, Su J, et al. (2013). Molecular cloning, characterization and expression analysis of coagulation factor VII gene in grass carp (Ctenopharyngodon idella). Fish Shellfish Immunol. 35: 618-622.

Peyvandi F, Palla R, Menegatti M, Siboni SM, et al. (2012). Coagulation factor activity and clinical bleeding severity in rare bleeding disorders: results from the European Network of Rare Bleeding Disorders. J. Thromb. Haemost. 10: 615-621.

Rhee JS, Jeong CB, Kim DH, Kim IC, et al. (2014). Immune gene discovery in the crucian carp Carassius auratus. Fish Shellfish Immunol. 36: 240-251.

Solomon D, Kim B, Scultetus A, Arnaud F, et al. (2011). The effect of rFVIla on pro- and anti-inflammatory cytokines in serum and cerebrospinal fluid in a swine model of traumatic brain injury. Cytokine 54: 20-23.

Su J, Heng J, Huang T, Peng L, et al. (2012). Identification, mRNA expression and genomic structure of TLR22 and its association with GCRV susceptibility/resistance in grass carp (Ctenopharyngodon idella). Dev. Comp. Immunol. 36: 450-462.

Tang Y, Yu J, Li H, Xu P, et al. (2013). Molecular cloning, characterization and expression analysis of multiple leptin genes in Jian carp (Cyprinus carpio var. Jian). Comp. Biochem. Physiol. B Biochem. Mol. Biol. 166: 133-140.

Tassanakajon A, Somboonwiwat K, Supungul P and Tang S (2013). Discovery of immune molecules and their crucial functions in shrimp immunity. Fish Shellfish Immunol. 34: 954-967.

Wang C, Dai J, Sun Z, Shi C, et al. (2015). Targeted inhibition of disheveled PDZ domain via NSC668036 depresses fibrotic process. Exp Cell Res. 331: 115-122.

Wong PC, Luettgen JM, Rendina AR, Kettner CA, et al. (2010). BMS-593214, an active site-directed factor VIla inhibitor: enzyme kinetics, antithrombotic and antihaemostatic studies. Thromb. Haemost. 104: 261-269.

Ye X, Tian YY, Deng GC, Chi YY, et al. (2012). Complete genomic sequence of a reovirus isolated from grass carp in China. Virus Res. 163: 275-283.

Zhang QL, Yan Y, Shen JY, Hao GJ, et al. (2013). Development of a reverse transcription loop-mediated isothermal amplification assay for rapid detection of grass carp reovirus. J. Virol. Methods 187: 384-389. 